\title{
Effect of dates of sowing and varieties on yield and quality of cluster bean (Cyamopsistetra gonoloba L.)
}

\author{
Sunil Kumar ${ }^{1 *}$, M. Martin Luther ${ }^{1}$, Vikram Kumar ${ }^{2}$ and K. Hemalatha ${ }^{2}$ \\ ${ }^{1}$ Department of Agronomy, Agricultural College, Bapatla-522 101(Andhra Pradesh), INDIA \\ ${ }^{2}$ Department of Agronomy, Institute of agricultural sciences, Banaras Hindu University, Varanasi-221005 (Uttar \\ Pradesh), INDIA \\ *Corresponding author. E-mail: skumar21787@gmail.com
}

Received: September 13, 2016; Revised received: February 13, 2017; Accepted: May 25, 2017

\begin{abstract}
A field experiment was conducted at Agricultural College Farm, Bapatla (Andhra Pradesh), study the effect of different sowing dates on the yield and quality of different varieties of clusterbean. The experiment was laid out in factorial randomized block design replicated thrice, six dates of sowing from $15^{\text {th }}$ September to $1^{\text {st }}$ December at fifteen days interval and two clusterbean varieties viz. RGC-936 and RGC-1003. Results revealed thatgrowth parameters, yield attributes, yield (1568 $\left.\mathrm{kg} \mathrm{ha}^{-1}\right)$ and quality parametersviz. gum content $(31.6 \%)$, protein content $(30.1 \%)$ and viscosity $(3783 \mathrm{cP})$ were highest with RGC-1003 sown at $15^{\text {th }}$ November, which was at par with $1^{\text {st }}$ December sowing with same variety. The study results showed that the clusterbean crop can be grown successfully in non-traditional area as a rabi crop.
\end{abstract}

Keywords: Clusterbean, Quality, Sowing dates, Varieties, Yield

\section{INTRODUCTION}

Cluster bean is an annual legume popularly known as gum guar, an important source of nutrition to human beings and animals. Being a legume, it has the capacity to fix up atmospheric nitrogen. The endosperm of guar seed is an important hydrocolloid widely used across a broad spectrum of industries. India is the largest producer of clusterbean and contributes to 80 per cent of total clusterbean production in the world. The area, production and productivity of clusterbean in India is 51.52 lakh hectares, 26.61 lakh tons and $478 \mathrm{~kg} \mathrm{ha}^{-1}$ respectively during 2012-13 (Ministry of Agriculture, Government of India,2014-15).It is grown mainly in Rajasthan, Gujarat, Haryana, and Punjab. The grain yield of clusterbean in India is extremely low and has been static over the last several decades. This may be due to the fact that efforts have not been made to find out the optimum agronomic requirements of this crop. Among other crop production factors, sowing time contributes a lot towards the yield potential. Henry and Kackar (2001) observed that guar genotypes interacted significantly with the environment in enhancing yield.

Therefore, considering the growing export demand and its various industrial uses there is a need to find out suitable sowing dateand variety of cluster bean to enhance productivity and quality as it is gaining popularity in nontraditional areas.

\section{MATERIALS AND METHODS}

The present investigation was conducted at Agricultural College Farm, Bapatla $\left(15^{\circ} 55^{\prime} \mathrm{N}\right.$ latitude and $80^{\circ} 30^{\prime}$ E longitudes, at an altitude of $4.29 \mathrm{~m}$ above mean sea level), Andhra Pradesh, India during rabi, 2014-15. The experimental field was clay loam, slightly alkaline in soil reaction ( $\mathrm{pH} 7.2)$ and EC is $\left(0.26 \mathrm{dsm}^{-1}\right)$, low in organic carbon $(0.48 \%)$ and available nitrogen $(190 \mathrm{~kg}$ $\left.\mathrm{ha}^{-1}\right)$, medium in available phosphorus $\left(22.0 \mathrm{~kg} \mathrm{ha}^{-1}\right)$ and high in available potassium $\left(290.5 \mathrm{~kg} \mathrm{ha}^{-1}\right)$. The mean maximum and mean minimum temperatures recoded during crop growth period were $31.1^{\circ} \mathrm{C}$ and $20.0^{\circ} \mathrm{C}$, respectively. The average relative humidity was 77.0 per cent. A total rainfall of $387.3 \mathrm{~mm}$ was received in 15 rainy days during the crop growth period. The experiment was conducted in randomized block design with factorial concept with three replications and consisted of six dates of sowing from $15^{\text {th }}$ September to $1^{\text {st }}$ December at fifteen days interval as the first factor and two clusterbean varieties viz. RGC-936 and RGC1003 as second factor. The inoculated seeds through Rhizobium culture were hand dibbled by adopting a spacing of $45 \mathrm{~cm} \times 10 \mathrm{~cm}$. The crop was supplied with recommended dose of fertilizer i.e., $20 \mathrm{~kg} \mathrm{~N}, 40 \mathrm{~kg}$ $\mathrm{P}_{2} \mathrm{O}_{5}$ and $40 \mathrm{~kg} \mathrm{~K}_{2} \mathrm{O} \mathrm{ha}^{-1}$ in the form of urea, single super phosphate and muriate of potash respectively. The gum content of clusterbean seed was determined by Das et al. (1977), protein content by (A.O.A.C, 1960) 
and viscosity of gum was measured by using Brookfield viscometer, Model RVF, at $60 \mathrm{rpm}$, spindle no.64.

\section{RESULTS AND DISCUSSION}

Growth parameters: The highest growth parameters (plant height, number of branches plant ${ }^{-1}$, drymatter accumulation, days for $50 \%$ flowering and days to maturity) were recorded with November $15^{\text {th }}$ sowing which was significantly superior to other dates of sowings (Table 1).However, it was also comparable with December $1^{\text {st }}$ sowing for plant height and dry matter accumulation.Incase of varieties, the highest growth parameters were recorded with the variety RGC-1003, which was significantly superior to RGC-936. A significant decrease in growth parameters were observed due to early sowings. This might be due to due to favorable climatic conditions prevailed during the crop growth period by late sown crop when compared to early sowings. More number of days for $50 \%$ flowering with late sowing might be due to low mean maximum and minimum temperatures coupled with lower bright sunshine hours and lesser day length, which might have increased vegetative growth and thus increased in days to $50 \%$ flowering. The growth parameters obtained were in accordance with those of Buttar and Kaur (2010) and (Meena et al., 2014).

Table 1. Growth parameters of clusterbean as influenced by dates of sowing and varieties.

\begin{tabular}{|c|c|c|c|c|c|}
\hline Treatments & $\begin{array}{l}\text { Plant height } \\
\text { (cm) }\end{array}$ & $\begin{array}{c}\text { Number of } \\
\text { branches plant }^{-1}\end{array}$ & $\begin{array}{c}\text { Dry matter } \\
\text { accumulation }\left(\mathrm{kg} \mathrm{ha}^{-1}\right)\end{array}$ & $\begin{array}{l}\text { Days to } 50 \% \\
\text { flowering }\end{array}$ & $\begin{array}{l}\text { Days to } \\
\text { maturity }\end{array}$ \\
\hline \multicolumn{6}{|c|}{ Dates of sowing } \\
\hline Sep. $15^{\text {th }}$ & 86.4 & 8.9 & 4756 & 32.5 & 97 \\
\hline Oct. $1^{\text {st }}$ & 87.9 & 9.4 & 5397 & 33.5 & 95 \\
\hline Oct. $15^{\text {th }}$ & 88.9 & 10.6 & 5581 & 35.0 & 101 \\
\hline Nov. $1^{\text {st }}$ & 92.4 & 11.1 & 7011 & 36.5 & 106 \\
\hline Nov. $15^{\text {th }}$ & 104.4 & 14.1 & 7849 & 40.5 & 112 \\
\hline Dec. $1^{\text {st }}$ & 102.9 & 12.6 & 7352 & 37.5 & 108 \\
\hline $\mathrm{SEm} \pm$ & 3.29 & 0.36 & 213.6 & 0.42 & 0.9 \\
\hline $\mathrm{CD}(\mathrm{P}=0.05)$ & 9.6 & 1.1 & 626 & 1.2 & 3 \\
\hline \multicolumn{6}{|l|}{ Varieties } \\
\hline RGC-936 & 89.9 & 11.1 & 5872 & 34.3 & 101 \\
\hline RGC-1003 & 97.7 & 11.2 & 6777 & 37.5 & 105 \\
\hline $\mathrm{SEm} \pm$ & 1.90 & 0.21 & 123.3 & 0.24 & 0.5 \\
\hline $\mathrm{CD}(\mathrm{P}=0.05)$ & 5.6 & NS & 361.7 & 0.7 & 1.5 \\
\hline
\end{tabular}

Table 2. Yield attributes of clusterbean as influenced by dates of sowing and varieties.

\begin{tabular}{|c|c|c|c|c|}
\hline Treatments & Pods branch $^{-1}$ & Pods plant $^{-1}$ & Seeds pod $^{-1}$ & Test weight \\
\hline \multicolumn{5}{|l|}{ Dates of sowing } \\
\hline September $15^{\text {th }}$ & 5.5 & 38.23 & 6.4 & 27.8 \\
\hline October $1^{\text {st }}$ & 5.9 & 44.97 & 6.6 & 29.2 \\
\hline October $15^{\text {th }}$ & 6.7 & 60.7 & 6.6 & 29.4 \\
\hline November $1^{\text {st }}$ & 7.2 & 86.57 & 6.9 & 29.6 \\
\hline November $15^{\text {th }}$ & 9.4 & 124.6 & 7.5 & 31.6 \\
\hline December $1^{\text {st }}$ & 8.3 & 110.6 & 7.2 & 30.7 \\
\hline $\operatorname{SEm} \pm$ & 0.35 & 3.68 & 0.06 & 0.29 \\
\hline $\mathrm{CD}(\mathrm{P}=0.05)$ & 1.0 & 10.8 & 0.2 & 0.9 \\
\hline \multicolumn{5}{|l|}{ Varieties } \\
\hline RGC-936 & 6.1 & 63.5 & 6.6 & 29.1 \\
\hline RGC-1003 & 8.2 & 91.7 & 7.1 & 30.3 \\
\hline $\mathrm{SEm} \pm$ & 0.20 & 2.13 & 0.03 & 0.17 \\
\hline $\mathrm{CD}(\mathrm{P}=0.05)$ & 0.6 & 6.2 & 0.1 & 0.5 \\
\hline
\end{tabular}


Sunil Kumar et al. / J. Appl. \& Nat. Sci. 9 (2): 1081 - 1084 (2017)

Table 3. Yield and quality of clusterbean as influenced by dates of sowing and varieties.

\begin{tabular}{|c|c|c|c|c|c|}
\hline Treatments & $\begin{array}{c}\text { Grain yield } \\
\text { (kg ha-1) }\end{array}$ & $\begin{array}{c}\text { Haulm yield } \\
\text { (kg ha-1) }\end{array}$ & $\begin{array}{c}\text { Gum content } \\
(\%)\end{array}$ & $\begin{array}{c}\text { Protein content } \\
(\%)\end{array}$ & Viscosity (cP) \\
\hline \multicolumn{6}{|l|}{ Dates of sowing } \\
\hline September $15^{\text {th }}$ & 721 & 3029 & 26.9 & 25.4 & 2672 \\
\hline October $1^{\text {st }}$ & 848 & 3292 & 28.4 & 27.0 & 3070 \\
\hline October $15^{\text {th }}$ & 1079 & 3580 & 29.4 & 27.9 & 3143 \\
\hline November $1^{\text {st }}$ & 1353 & 3708 & 29.5 & 28.0 & 3473 \\
\hline November $15^{\text {th }}$ & 1568 & 3929 & 31.6 & 30.1 & 3783 \\
\hline December $1^{\text {st }}$ & 1491 & 3740 & 30.8 & 29.3 & 3533 \\
\hline $\mathrm{SEm} \pm$ & 46.0 & 139.0 & 0.34 & 0.35 & 57.7 \\
\hline $\mathrm{CD}(\mathrm{P}=0.05)$ & 135 & 408 & 1.00 & 1.04 & 169 \\
\hline \multicolumn{6}{|l|}{ Varieties } \\
\hline RGC-936 & 1071 & 3263 & 28.3 & 26.9 & 2926 \\
\hline RGC-1003 & 1283 & 3829 & 30.5 & 29 & 3633 \\
\hline $\mathrm{SEm} \pm$ & 26.5 & 80.2 & 0.20 & 0.20 & 33.3 \\
\hline $\mathrm{CD}(\mathrm{P}=0.05)$ & 78 & 235 & 0.6 & 0.6 & 98 \\
\hline
\end{tabular}

Yield attributes: The highest yield attributes (number of pods branch ${ }^{-1}$, number of pods plant ${ }^{-1}$, number of seeds $\operatorname{pod}^{-1}$ and test weight) was observed with $15^{\text {th }}$ November sowing, which was significantly superior to the rest of sowing dates (Table 2). With regard to the varieties, the maximum yield attributes was recorded with RGC-1003 and was significantly superior to RGC -936. Higher yield attributes recorded with late sowing might be due to optimum weather conditions coupled with more growing days during reproductive phase which might have helped in transformation of more assimilates and subsequently develop more yield attributes with delayed sowing, whereas, in early sowings crop was affected with high amount of rainfall and lesser growing days during reproductive phase might have reduced the yield attributes. Similar results were also reported in case of yield attributes of clusterbean in similar weather conditions by Lakshmi Kalyani (2012).

Yield: Among dates of sowing the highest grain yield was recorded $15^{\text {th }}$ November sowing which was on a par with $1^{\text {st }}$ December sowing (Table 3). Between varieties, the highest grain yield was recorded with RGC-1003 which was significantly superior to RGC936. Similar trend was followed by haulm yield. The higher grain yield with delay sowing might be due to combined effects of higher values recorded for growth characters and yield attributing characters as well as favourable weather conditions like optimum temperature, more sunshine hours and rainless maturity period that prevailed during grain filling and maturity stages of the crop growth whereas, in earlier date of sowings weather conditions were not favorable. The present results in relation to yield of clusterbean were also in accordance with those of Veera Jain et al. (1987)and Gill et al. (2012). With regard to the varieties, the highest grain yield was recorded with RGC-1003 which was significantly superior to that of RGC-936. This might be due to higher number of pods per plant, number of seeds per pod, test weight with variety RGC 1003.

Quality parameters: The maximum gum content, protein and viscosity were observed with $15^{\text {th }}$ November sowing followed by $1^{\text {st }}$ December. With regard to the varieties, the maximum gum content, protein and viscosity was recorded with RGC-1003 which was significantly superior to RGC-936.A significant decrease in quality was observed due to early sowings. This might be due to the decreased Growing Degree Days (GDDs) and high amount of rainfall during crop growing period experienced by early sown crop when compared to late sowings. Longer the day length during reproductive stage as well as favourable weather conditions that prevailed during grain filling and maturity stages of the crop growth is helpful in improving the quality of clusterbean. Kumar and Rodge (2012) also observed that summer sown guar gave higher gum content and viscosity of guar gum than kharif season sown in South India.

\section{Conclusion}

The clusterbean crop sown during second fortnight of November found to be the optimum time of sowing for getting higher yield (1568 $\left.\mathrm{kg} \mathrm{ha}^{-1}\right)$ and quality viz. gum content $(31.6 \%)$, protein content $(30.1 \%)$ and viscosity $(3783 \mathrm{cP})$. Between varieties, an overall performance of variety RGC-1003 was the best over RGC-936. In conclusion, the clusterbean crop can be grown 
successfully in non-traditional area of Southern India as a rabi crop.

\section{REFERENCES}

Anonymous (2015). Agricultural statistics at a glance. Department of Agriculture, Cooperation \& Farmers Welfare. Ministry of Agriculture, Government of India.

Association of Official Agricultural Chemists (1960). Official methods of Analysis, Washington D C $9^{\text {th }}$ Ed. (A.O.A.C).

Buttar, G.H. and Anureet Kaur. (2010). Performance of different genotypes of clusterbean (Cyamopsistetra gonoloba) under various sowing dates. Crop Science, 39 (1, 2 \& 3): 62-64

Das, B., Arora, S.K. and Singh, K. 1(977). A rapid method for determination of gum in guar (Cyamopsistetra gonoloba (L.) Taub.). Proceedings of $1^{\text {st }}$ ICAR Guar Research Workshop, Jodhpur. 117-123

Gill, R.K., Manpreet Singh, Sarvjeet Singh and Johar Singh. (2012). Effect of sowing dates and fertility levels on grain yield and its component traits in lentil. Journal of Food Legumes, 25(2): 159-161

Henry, A. and Kackar, N.L. (2001). Studies on phenotypic stability in cluster bean under late sown conditions. Current Agriculture, 25(1-2):103-105

Kumar, D. and Rodge, A.B. (2012). Status, scope and strategies of arid legumes research in India- A review. Journal of food legumes, 25 (4): 255-272

Lakshmi Kalyani, D. (2012). Performance of clusterbean genotypes under varied time of sowing. Legume Research, 35 (2): 154-158

Meena, V.K., Kaushik,M.K., Meena, R.S., Meena, V.S. and Meena, B.P. (2014). Effect of growth regulators on clusterbean (Cyamopsistetra gonoloba (L.) growth under Aravali hills improvement in Rajasthan. The bioscan, 9 (2): $547-550$

Veera Jain, Yadav, B.D., Sharma, B.D. and Taneja, K.D. (1987). Effect of dates of sowing, row spacing and varaities on yield and quality of clusterbean (Cyamopsistetra gonoloba L.)Taub.). Indian Journal of Agronomy, 32(4): 378-382 